\title{
Changes and Challenges of Climate in India
}

\author{
*Ashutosh Mishra \\ Geography Department, University of Allahabad, India \\ Submission: August 08, 2017; Published: August 28, 2017 \\ *Corresponding author: Geography Department, University of Allahabad, Email: ashutoshkmisra@gmail.com
}

\begin{abstract}
Climate is a critical factor that determines the habitability of a place. India is a vast country, in terms of population and also in terms of diversity, and any significant change in the climatic conditions will affect country`s physical and social setup. Agriculture, health, biodiversity, natural disasters etc. are the major challenges that the country will have to face in changing climatic regimes. Present paper has analyzed the temperature and rainfall data of past 102 (1911-2012) years to know the climatic changes during the past century. It is observed that while temperature has witnessed a significant rise over almost all the parts of the country, rainfall has a two-tailed trend. The state level analysis reveal that out of total 36 states, half of the number (18) have recorded an increase and rest have witnessed a decline in rainfall. Whatsoever trends are, they indicate that climate is changing (somewhere significantly, somewhere underway), and we need to devise policies in favour of environmental conservation and will have to adopt resource frugal living as has been suggested by the old Hindu scriptures.
\end{abstract}

Keywords: Humanogenic enhancement; Chaotic system; Geomorphic processes; Physio-climatic condition; Societal diversity; Heterogeneous topography; Interglacial phase

\section{Introduction}

Earth`s climate has changed throughout all the course of its history and will continue changing in future also as the factors determining properties of the climate at a place are changeable due to dynamic nature of Earth and various solar ingredients. However, besides these forces, human activities are also considered as a factor of change in climate owing to his potentially increasing perturbations in the land, water and air systems. Passing through scholarly works of Joseph Fourier [1], John Tyndall [2], Svante Arrhenius [3], TC Chamberlin [4], GS Callendar [5] and CD Keeling [6] our knowledge about heat retaining capacity of atmospheric gases and their humanogenic enhancement in the air has increased several folds. Undoubtedly the human activities are polluting all the three basic ingredients of nature- the land, the water and the atmosphere by adding something unnatural or unwanted in these systems.

Although, there are naturally operating feedbacks that work to neutralize the enhanced effects up to a limit, but when the change becomes unmanageable, it may result in to a catastrophe. Climate is a chaotic system which fate depends on its initial state, and, therefore, changing the initial will change the fate. In simple words, we can say that current atmospheric (/climatic) properties will decide the future climate. And, this is all about our concern for climate change. If we are changing, the change will happen, but it may be catastrophic.

\section{India's Concern}

The physical and social settings of India are quite varied. Its large agriculture base, Himalayan-fed plains, huge rural population, and dense rural and urban settlements make it a climatologically sensitive state. For a long time the Indian glaciers have been in the center of climate change debate, and it is feared that in near future they may witness a significant loss in volume due to rise in surface temperature. This change will also affect the livelihood of a large part of country`s population that depends on river waters originating from the melt of these glaciers to meet their variety of needs viz. irrigation, drinking etc. In addition to this, the melting of glaciers at a faster rate will speed up the geomorphic processes that may lead to frequent landslides and floods.

India is a diversified country and the challenges that it may face due to climate change, are multi facet. While temperature changes can adversely affect the quantum and spatial pattern of rainfall resulting into drought and flood like situations in different parts of the country, changes in normal rainfall pattern can affect Indian agriculture very adversely. Destruction of forests due to arid situations, forest fire and loss in mangrove cover due to change in coastal water are likely impacts of climatic changes. Forests nurture a great wealth of biodiversity and their removal or extinction will not only affect human 
society but will also pose a great threat to this vast biological world. India's coastal areas are highly vulnerable to cyclones that may affect the human habitat and livelihood in these regions. Salinization of agricultural land due to sea level changes and the possibility of loss in productivity of fisheries are also the probable changes that we may face in future. Climate related changes will also increase the risk from diseases like respiratory and cardiovascular ailments, vector-borne infections, heat stress and smog-induced respiratory illnesses etc. These health issues are another area of concern for the country as a large part of India`s population lives below poverty line.

Undoubtedly country's unique physio-climatic condition and its societal diversity make it vulnerable to climate change, and therefore, accurate estimation of ongoing and possible future

Table 1: Annual Mean Temperature Changes over India during 1911-2012.

\begin{tabular}{|c|c|c|c|c|c|}
\hline $\begin{array}{l}\text { States Witnessing } \\
\text { Increase in } \\
\text { Temperature }\end{array}$ & $\begin{array}{l}\text { Temperature Trend } \\
\text { in }{ }^{\circ} \mathrm{C} / 100 \text { Years }\end{array}$ & $\begin{array}{c}\text { States Witnessing } \\
\text { Significant Increase } \\
\text { in Temperature at } \\
\text { 95\% Confidence } \\
\text { Level }\end{array}$ & $\begin{array}{l}\text { Temperature Trend } \\
\text { in }{ }^{\circ} \mathrm{C} / 100 \text { Years }\end{array}$ & \begin{tabular}{|c|} 
States Witnessing \\
Significant Increase \\
in Temperature at \\
$99 \%$ Confidence \\
Level
\end{tabular} & $\begin{array}{l}\text { Temperature Trend } \\
\text { in }{ }^{\circ} \mathrm{C} / 100 \text { Years }\end{array}$ \\
\hline Chandigarh & 0.32 & Rajasthan & 0.33 & Telangana & 1.13 \\
\hline NCT of Delhi & 0.30 & & & Andhra Pradesh & 0.87 \\
\hline Punjab & 0.23 & & & Puducherry & 0.79 \\
\hline \multirow[t]{24}{*}{ Haryana } & 0.22 & & & Arunachal Pradesh & 0.71 \\
\hline & & & & Karnataka & 0.71 \\
\hline & & & & Assam & 0.70 \\
\hline & & & & Tamil Nadu & 0.68 \\
\hline & & & & Goa & 0.67 \\
\hline & & & & Maharashtra & 0.67 \\
\hline & & & & Nagaland & 0.66 \\
\hline & & & & Kerala & 0.64 \\
\hline & & & & Chhattisgarh & 0.63 \\
\hline & & & & Sikkim & 0.63 \\
\hline & & & & Madhya Pradesh & 0.60 \\
\hline & & & & Gujrat & 0.58 \\
\hline & & & & Manipur & 0.56 \\
\hline & & & & Meghalaya & 0.55 \\
\hline & & & & Jammu and Kashmir & 0.54 \\
\hline & & & & West Bengal & 0.54 \\
\hline & & & & Mizoram & 0.50 \\
\hline & & & & Tripura & 0.50 \\
\hline & & & & $\begin{array}{l}\text { Andaman and } \\
\text { Nicobar }\end{array}$ & 0.49 \\
\hline & & & & \begin{tabular}{|l} 
Dadra and Nagar \\
Haveli
\end{tabular} & 0.49 \\
\hline & & & & Daman and Diu & 0.49 \\
\hline & & & & Lakshadweep & 0.49 \\
\hline & & & & Jharkhand & 0.48 \\
\hline & & & & Odisha & 0.48 \\
\hline
\end{tabular}

changes is of utmost importance. Present paper attempts to map the temperature and rainfall changes over India during last 100 years and suggests ways to address the challenges emanating from these changes. The analysis uses a 102 years (1911-2012) temperature and rainfall dataset of the country, obtained from IMD, Pune and India water portal, and a simple trend analysis was performed to figure out the changes.

\section{Changes in Temperature and Rainfall Patterns over India}

The analysis reveals that during the last century while the temperature over the country has increased $\left(+0.54^{\circ} \mathrm{C} / 100\right.$ Years), the rainfall has declined ( $-9 \mathrm{~mm} / 100$ Years) (Figure 1). The results of trend analysis for temperature changes over states have been presented in Table 1. 


\section{International Journal of Environmental Sciences \& Natural Resources}

\begin{tabular}{|l|l|l|l|l|l|}
\hline & & & & Bihar & 0.47 \\
\hline & & & & Uttarakhand & 0.46 \\
\hline & & & & Himachal Pradesh & 0.44 \\
\hline & & & & Uttar Pradesh & 0.40 \\
\hline
\end{tabular}

Source: Computed.

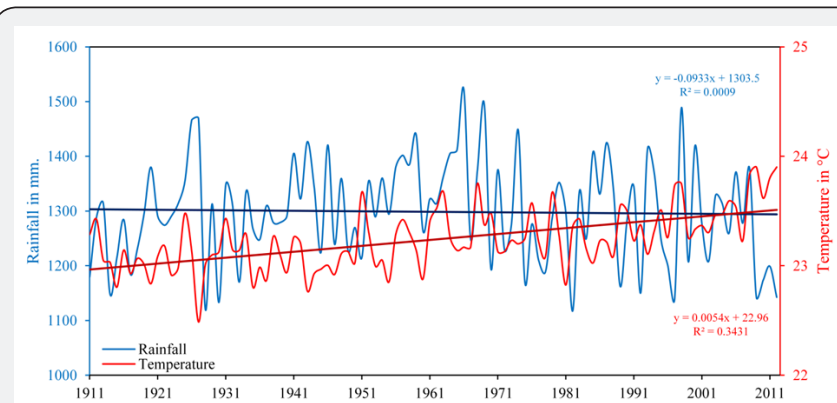

Figure 1: Annual Mean Temperature and Annual Rainfall Trend over India.

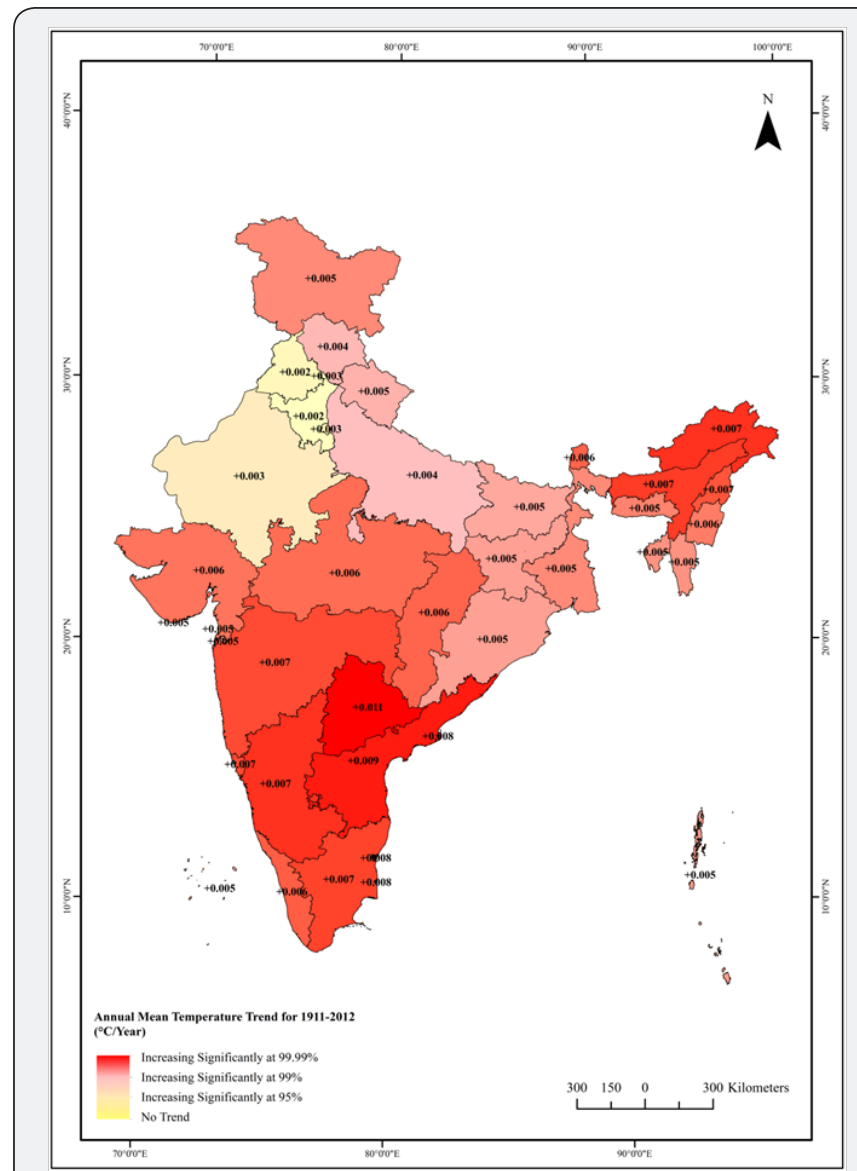

Figure 2: Temperature Changes over India during Past 102 Years (1911-2012).

The analysis clearly shows that out of 36 states, 32 have recorded a significant warming during the last century. Interestingly the southern states have witnessed maximum rise in temperature. Although, a continuous belt comprising of four states- Chandigarh, NCT of Delhi, Punjab and Haryana did not show any significant warming, but even temperature was on rise in this belt also during the past century. Overall 17 states have shown more warming than the country as a whole $\left(0.54^{\circ} \mathrm{C}\right)$. The states of Jammu and Kashmir and West Bengal warmed equally as compared to India, while 12 states were below the national mark (Figure 2). It is noteworthy that poverty stricken and densely populated states are low on warming while the fastgrowing coastal states are on the warmer side.

The analysis of the rainfall trend at the national level shows a negative but insignificant change of $0.9 \mathrm{~cm}$. during the last century. Obviously, the average quantum of rainfall over 102 years has declined which is very revealing. As shown in Figure 1 , there are several spells of increase and decline in rainfall, however, the overall pattern is quite noisy and fluctuating. The state level analysis of rainfall patterns has been shown in Table 2. It is very interesting to note that out of 36 states, half of the states (18) have recorded an increasing while the rest half of the states (18) have recorded a decreasing rainfall trend during the last century. There are only 8 states which demonstrate any significant change in the rainfall. Out of these 8 states, 6 states namely NCT of Delhi, Punjab, Jammu and Kashmir, Telangana, Haryana and Andhra Pradesh have recorded a significant increase while the states of Bihar and Chhattisgarh have witnessed a decrease in rainfall (Figure 3).

Table 2: Annual Rainfall Changes over India during 1911-2012.

\begin{tabular}{|c|c|c|c|}
\hline $\begin{array}{l}\text { States Witnessing } \\
\text { Increase in Rainfall }\end{array}$ & $\begin{array}{l}\text { Rainfall Trend in } \\
\mathrm{cm} . / 100 \text { Years }\end{array}$ & $\begin{array}{c}\text { States } \\
\text { Witnessing } \\
\text { Decrease in } \\
\text { Rainfall }\end{array}$ & $\begin{array}{c}\text { Rainfall } \\
\text { Trend in } \\
\mathrm{cm} . / 100 \\
\text { Years }\end{array}$ \\
\hline \multicolumn{2}{|c|}{ Significant Increase at 99\% } & \multicolumn{2}{|c|}{$\begin{array}{c}\text { Significant Decrease at } \\
99 \%\end{array}$} \\
\hline NCT of Delhi & 16.10 & Bihar & 19.69 \\
\hline Punjab & 11.24 & & \\
\hline \multicolumn{2}{|c|}{ Significant Increase at 95\% } & \multicolumn{2}{|c|}{$\begin{array}{l}\text { Significant Decrease at } \\
95 \%\end{array}$} \\
\hline Jammu and Kashmir & 15.27 & Chhattisgarh & 12.28 \\
\hline Telangana & 12.07 & & \\
\hline Haryana & 10.62 & & \\
\hline Andhra Pradesh & 9.54 & & \\
\hline \multicolumn{2}{|c|}{ Increasing } & \multicolumn{2}{|c|}{ Decreasing } \\
\hline $\begin{array}{c}\text { Dadra and Nagar } \\
\text { Haveli }\end{array}$ & 8.39 & Nagaland & 15.44 \\
\hline Puducherry & 7.88 & Manipur & 14.80 \\
\hline Chandigarh & 7.72 & Jharkhand & 13.61 \\
\hline Himachal Pradesh & 4.56 & Uttarakhand & 13.05 \\
\hline
\end{tabular}




\begin{tabular}{|c|c|c|c|}
\hline Rajasthan & 2.79 & Sikkim & 12.53 \\
\hline $\begin{array}{c}\text { Andaman and } \\
\text { Nicobar }\end{array}$ & 2.71 & Tripura & 11.93 \\
\hline Lakshadweep & 2.71 & Mizoram & 8.87 \\
\hline Tamil Nadu & 2.71 & Assam & 6.71 \\
\hline West Bengal & 2.13 & Uttar Pradesh & 6.65 \\
\hline Kerala & 1.29 & $\begin{array}{c}\text { Arunachal } \\
\text { Pradesh }\end{array}$ & 5.71 \\
\hline Goa & 1.10 & Karnataka & 3.24 \\
\hline Maharashtra & 1.10 & Meghalaya & 2.99 \\
\hline & & $\begin{array}{c}\text { Madhya } \\
\text { Pradesh }\end{array}$ & 2.98 \\
\hline & & $\begin{array}{c}\text { Daman and } \\
\text { Diu }\end{array}$ & 1.30 \\
\hline & & Gujrat & 1.30 \\
\hline & & Odisha & 0.42 \\
\hline
\end{tabular}

Source: Computed.

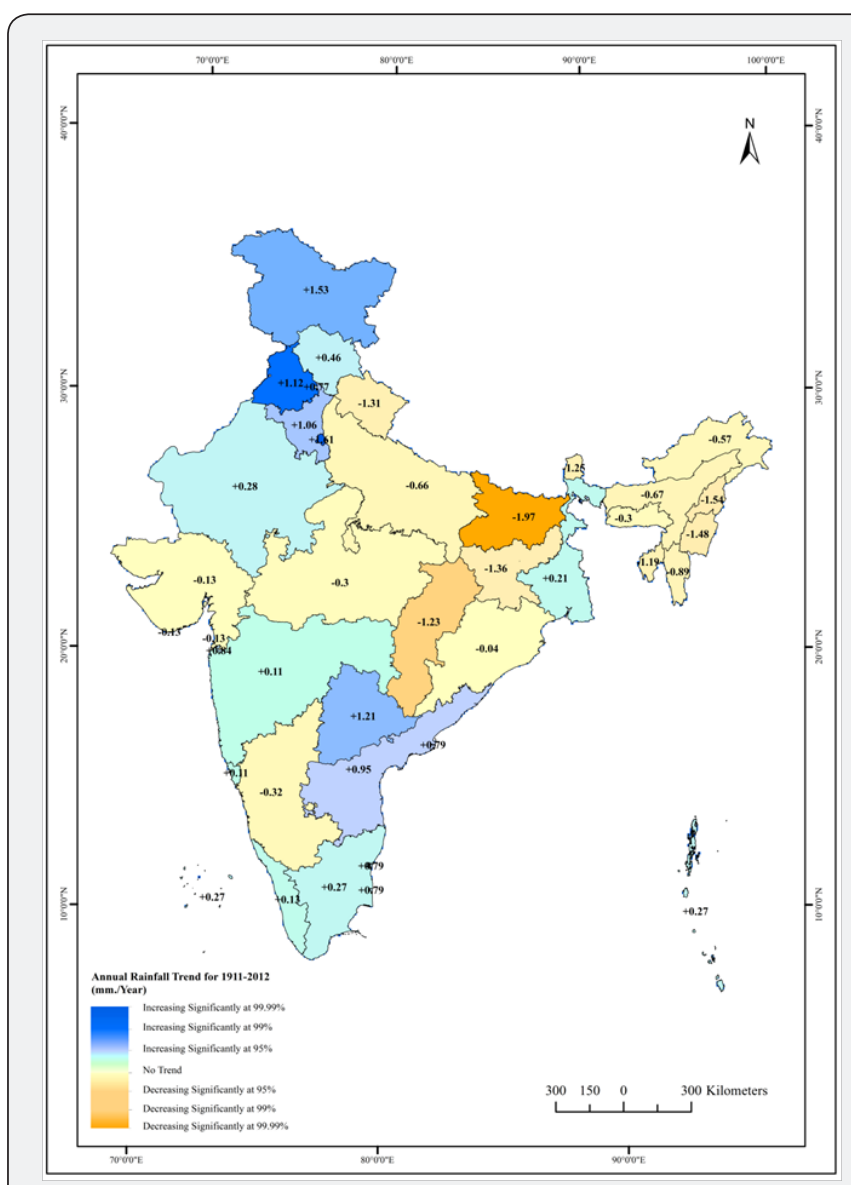

Figure 3: Rainfall Changes over India during Past 102 Years (1911-2012).

The regression results indicate that the states which ones witnessed high rainfall are likely to experience either drought or comparatively less rainfall in the coming years. It is also interesting to note that the states such as Punjab, NCT of Delhi, Haryana and Chandigarh, where the temperature trend was not significant, have witnessed positive change in rainfall. It is evident that the most poverty-stricken states like Bihar, Jharkhand, Odisha, Chhattisgarh, Uttar Pradesh and the major rain fed agricultural regions of the country- the Ganga Plains, are facing rainfall deficit. Overall, it may be said that temperature is witnessing a rising trend whereas rainfall on an average has shown a declining trend. The state level analysis, however, does not categorically support this outcome because there are several regional variations. The data analysis, on the whole, reveals that the southern part is more fragile in terms of variation in temperature because this is likely to witness greater rise in temperature as compared to the northern part of India.

\section{Conclusion}

Temperature is the most important parameter that controls the overall weather and climate of a place, and once it undergoes uneven changes, it may intensify the general impacts of climate change. Due to heterogeneous topography and climatic conditions, the rise in the surface temperature is not the same over all parts of the country, and it was observed that the fragile ecosystems (like mountains) are more vulnerable to change than comparatively stable ecosystems (like plains). The Northwest region of the country, which is the key to trigger monsoon, has recorded moderate while the Southern region has recorded a very significant rise in temperature during the past century. This has great bearing on the pressure gradient between these two monsoon defining locations. This is an indication of weak monsoon and its untimely trigger over the Indian Sub-continent. The uneven warming trend has developed local warm patches affecting the monsoon mechanism.

This local influence has fragmented the Indian monsoon and increased the frequency and intensity of climatological disasters in the country. The Indian mountains are warming significantly and, thus, are attracting more clouds and torrential rains. Heavy rain increases the viscosity between rock layers and as a result often brings massive landslide in these areas. High temperatures than usual in the coastal and North-east regions of the country have increased the instances of storms occurrences in recent time. Extended deep-depression over these regions provide more energy to cyclonic winds on account of which these cyclones are becoming more lethal day by day, even after sufficient technological development and increased awareness.

\section{References}

1. Fourier J (1824) RemarquesGénérales Sur Les Temperatures Du Globe Terrestre Et Des EspacesPlanétaires. Annales de Chemie et. de Physique 27: 136-67.

2. Tyndall J (1861) On the Absorption and Radiation of Heat by Gases and vapours, and on the Physical Connection of Radiation, Absorption and Conduction. Philosophical Magazine 4: 273-85.

3. Arrhenius S (1896) On the Influence of Carbonic Acid in the Air upon the Temperature of the Ground. Philosophical Magazine 41: 237-276.

4. Chamberlin TC (1897) A Group of Hypotheses Bearing on Climatic Changes. J Geology 5(7): 653-683. 
5. Callendar GS (1938) The Artificial Production of Carbon Dioxide and its Influence on Climate. Quarterly J Royal Meteorological Society 64: 223-240.
6. Keeling CD (1960) The Concentration and Isotopic Abundances of Carbon Dioxide in the Atmosphere. Tellus 12(2): 200-203.

Your next submission with Juniper Publishers will reach you the below assets

- Quality Editorial service

- Swift Peer Review

- Reprints availability

- E-prints Service

- Manuscript Podcast for convenient understanding

- Global attainment for your research

- Manuscript accessibility in different formats ( Pdf, E-pub, Full Text, Audio)

- Unceasing customer service

Track the below URL for one-step submission https://juniperpublishers.com/online-submission.php 